\title{
The adsorption behaviour of two commercial IgG-preparations onto a polystyrene latex surface
}

\author{
J.A. Ronner, H.G.W. Lensen, F.M.F.G. Olthuis*, C.A. Smolders and J. Feijen \\ Department of Chemical Technology, Twente University of Technology, P. O. Box 217, 7500 AE Enschede, The Netherlands \\ *Department of Clinical Chemistry, Stadsmaten Hospital, P.O. Box 5001, 7500 GA Enschede, The Netherlands \\ (Received 30 November 1983; accepted 11 January 1984)
}

\begin{abstract}
The adsorption behaviour of two commercial preparations of human IgG onto a polystyrene latex surface was studied. The adsorption isotherms obtained differed markedly; one proparation showed a plateau value of $0.4 \mu \mathrm{g} \mathrm{cm}^{-2}$ which was reached at $0.1 \mathrm{~g} \mathrm{I}^{-1}$, whereas the other preparation showed no plateau value within the concentration range studied $\left(0.1-7.0 \mathrm{~g} \Gamma^{-1}\right)$. Characterization by means of iso-electric focusing and HPLC also showed differences between the two preparations. No differences were observed when immuno-electrophoresis was carried out. These results stress the necessity for proper characterization of proteins used in adsorption studies.
\end{abstract}

Keywords: Polymers, surface properties, protein adsorption, immuno-globulin G, polystyrene latex, solution-depletion, protein characterization

Many studies concerning protein adsorption onto solid surfaces have been reported ${ }^{1-14}$. In only a few studies ${ }^{1.2 .8 .11 .13}$ was attention paid to the characterization of the protein used (Immuno-globulin G, IgG, for all references mentioned above).

The purpose of this study was to compare the adsorption behaviour of two lgG-preparations, obtained from different manufacturers, on to a polystyrene latex surface. Adsorbed amounts of protein were determined by means of solution-depletion measurements. Both IgGpreparations were characterized by HPLC, iso-electric focusing and immuno-electrophoresis.

\section{MATERIALS AND METHODS}

Human IgG obtained from Kabi AB. Stockholm, Sweden (KIgG; batch no. 78185) was prepared from Cohn fraction II + III. After precipitation with alcohol in the cold, chromatography on DEAE Sephadex was carried out, followed by freeze-drying. The total protein content was $95 \%$, of which $98 \%$ was $\operatorname{lgG}^{15}$.

Human IgG, obtained from the Centraal Laboratorium van de Bloedtransfusiedienst. Amsterdam, The Netherlands ( $\mathrm{ClgG}$ ) was prepared from Cohn fraction $\mathrm{II}+$ III. It was precipitated with alcohol in the cold and then freeze-dried ${ }^{15}$. The total protein content was $74 \%$ (as determined in our laboratory).

The proteins were characterized by HPLC (High Performance Liquid Chromatography) using a TSK-Gel SW 3000 column. Solutions $\left(2.0 \mathrm{~g} \mathrm{I}^{-1}\right)$ were made in elution buffer [Tris(hydroxymethyl)-aminomethane in
$0.05 \mathrm{M} \mathrm{H}_{2} \mathrm{SO}_{4} ; \mathrm{pH} \mathrm{7.0]} \mathrm{and} \mathrm{eluted} \mathrm{at} \mathrm{a} \mathrm{rate} \mathrm{of} 1.0 \mathrm{ml} \mathrm{min.}{ }^{-1}$. Iso-electric focusing was performed on both IgG-samples using the method described by Righetti and Drysdale ${ }^{16}$. Immuno-electrophoresis was carried out following the method of Grabar ${ }^{17}$.

Polystyrene (PS) latex was obtained from Serva (Dow), [lot no. 41932; specific surface area $15 \mathrm{~m}^{2} \mathrm{~g}^{-1}$; polystyrene content $10 \%(\mathrm{w} / \mathrm{w})$; density $1.0 \mathrm{~g} \mathrm{I}^{-1}$; diameter latex particles $399 \mathrm{~nm}$ according to SEM]. Before use the latex was dialysed against PBS (Phosphate Buffered Saline; $0.01 \mathrm{M} \mathrm{NaH} \mathrm{PO}_{4} \cdot 2 \mathrm{H}_{2} \mathrm{O} ; 0.15 \mathrm{M} \mathrm{NaCl}$; $\mathrm{pH} 7.35)$ : polystyrene content after dialysis was $8 \%(\mathrm{w} / \mathrm{w})$.

Samples for the adsorption experiments were prepared starting with protein solutions in PBS. To these solutions appropriate amounts of PS-latex were added. The samples (protein concentration $0.1-7.0 \mathrm{~g} \mathrm{l}^{-1}$ ) were then mixed and placed in a thermostatted water bath at $37^{\circ} \mathrm{C}$. After an adsorption time of $3 \mathrm{~h}$ the latex particles were removed by filtration $10.2 \mu \mathrm{m}$ red rim filter Schleicher and Schüll, type FP 030/3). Adsorbed amounts of protein were determined by measuring the (decrease of protein concentration in the filtrate using u.v.spectroscopy at $\lambda=280 \mathrm{~nm}$ (solution-depletion technique ${ }^{18}$ ).

\section{RESULTS}

\section{Characterization}

Figure 1 shows HPLC-chromatograms for both IgG- 


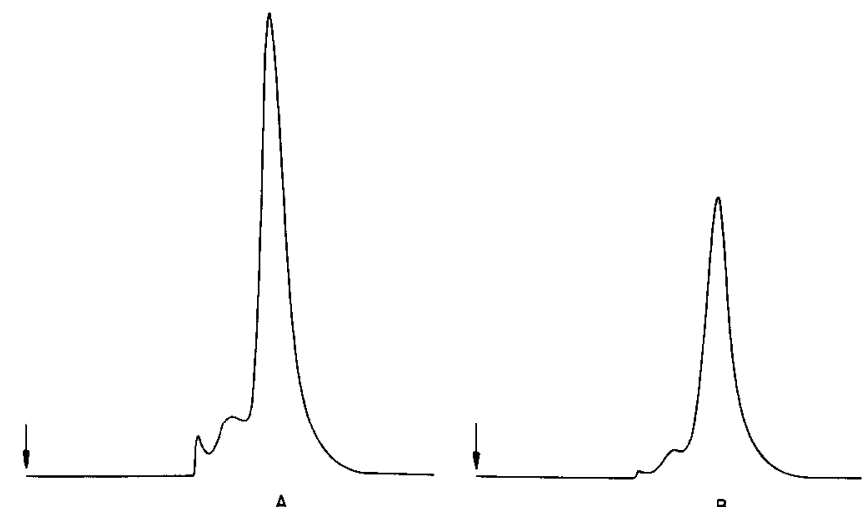

Figure 1 HPLC-chromatograms of $K I g G(A)$ and $C / g G(B)$ by refractive index detection at $20^{\circ} \mathrm{C} ; 100 \mathrm{\mu}, 2.0 \mathrm{~g} \Gamma^{-1}$ injected at the point indicated by the arrow. Elution volumes of main fractions: (A) $6.83 \mathrm{ml}$; (B) $6.57 \mathrm{ml}$

preparations. It can be observed that $\mathrm{KIgG}$ contains more high-molecular weight components than ClgG.

Figure 2 shows the results of the iso-electric focusing experiments with $\mathrm{KIgG}$ and $\mathrm{ClgG}$. ClgG contains protein components with iso-electric points (I.E.P.) in the low-pH range $(5.2<\mathrm{pH}<7.0)$, whereas KIgG does not contain any components with an I.E.P. $<\mathrm{pH} 7.0$. Immunoelectrophoresis results do not show differences between the two preparations.

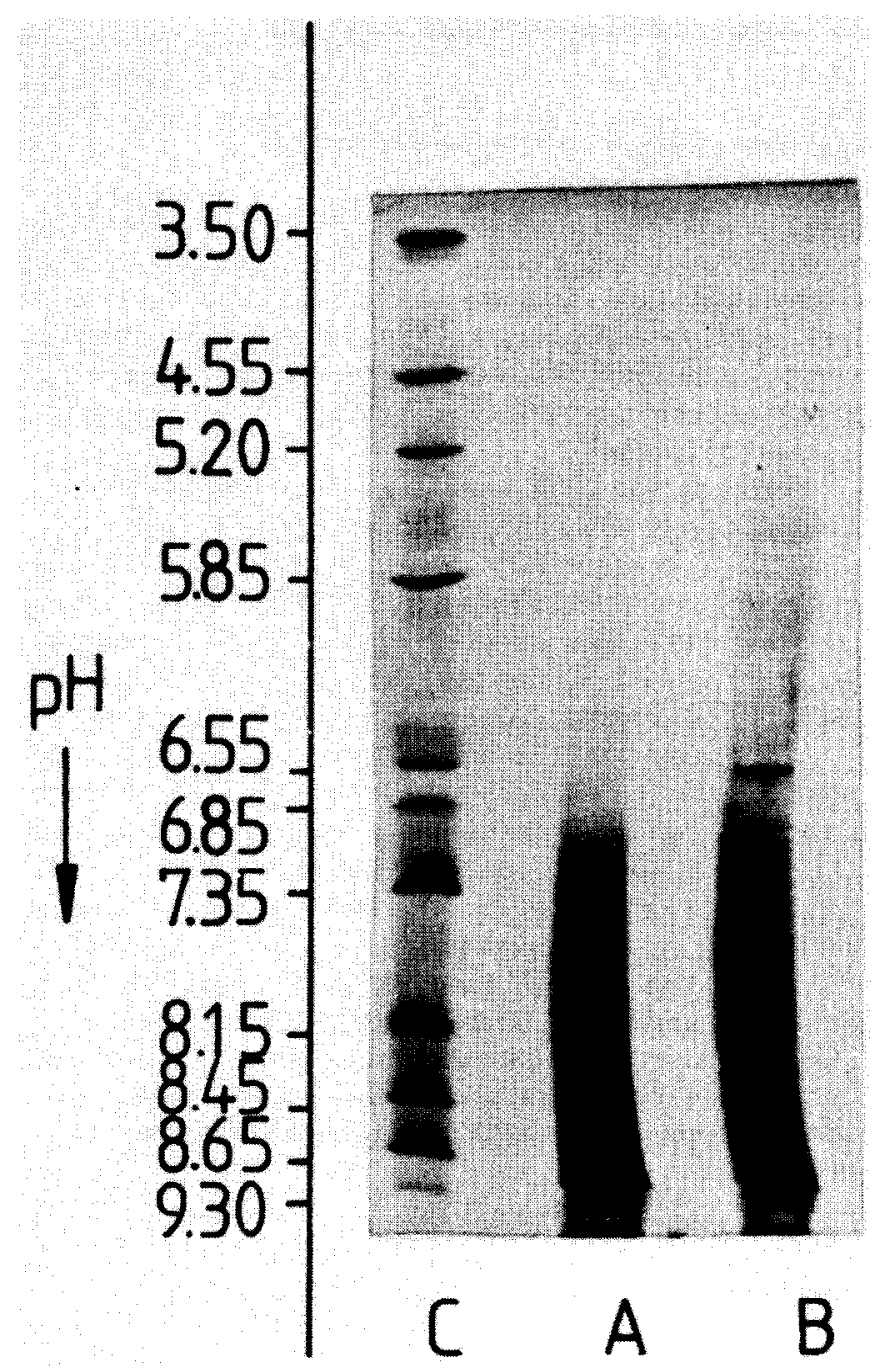

Figure 2 Iso-electric focusing results: $C$, calibration kit $p H$ 3-1O (Hoechst); A, KlgG;B, ClgG

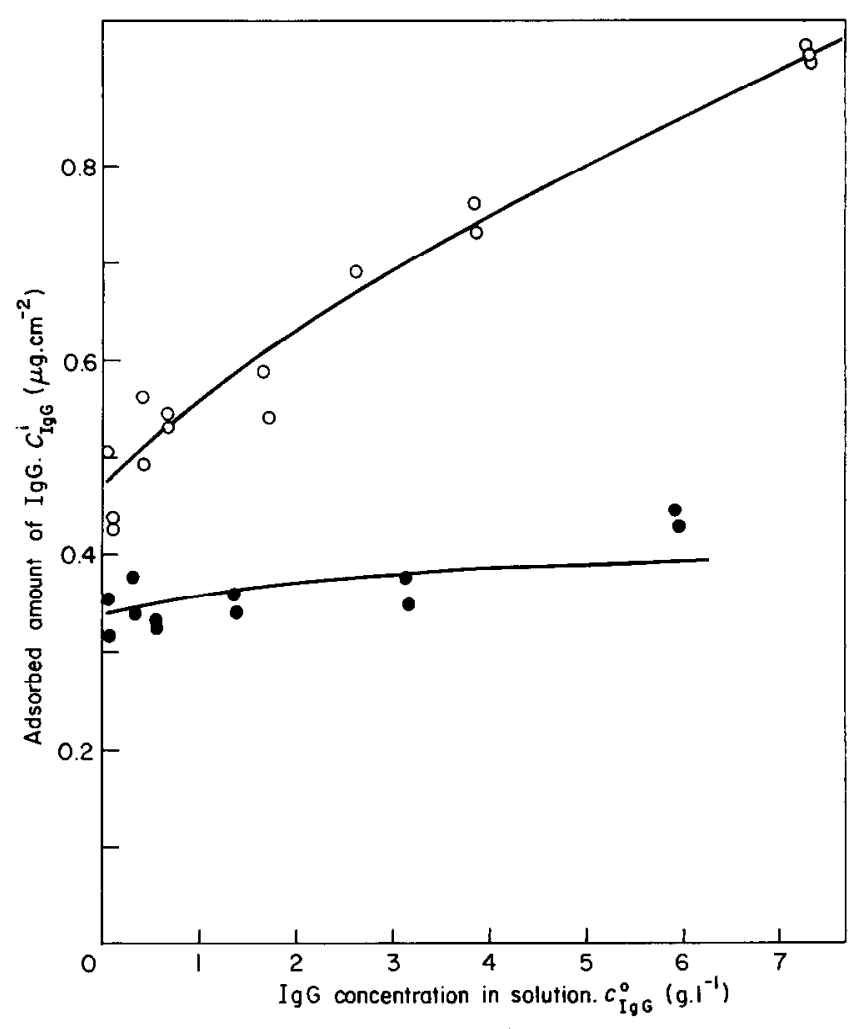

Figure 3 Adsorption isotherms for $K I g G(O)$ and $C / g G(\bullet)$ on to polystyrene latex: adsorbed amount of $/ g G$ ( $c_{\text {IgG }}^{\prime}$ l versus IgG-conicentration in solution $/ c_{\text {igd }}^{\circ}$

\section{Adsorption experiments}

Figure 3 shows the adsorption isotherms for KlgG and ClgG, respectively. Adsorption kinetics (data not incorporated in this paper) showed that an adsorption time of $3 \mathrm{~h}$ was sufficient for this system to reach equilibrium.

The adsorption isotherm for $\mathrm{Clg}$ G reaches a plateau value at low solution concentrations $10.4 \mu \mathrm{g} \mathrm{cm}^{-2}$ at $\left.0.1 \mathrm{~g} \mathrm{l}^{-1}\right)$, whereas the isotherm for KIgG does not reach a plateau at all within the concentration range studied. The adsorption isotherm appears to be typical for high-affinity adsorption in both samples.

\section{DISCUSSION}

IgG forms a rather heterogeneous group of proteins and therefore different preparation techniques in principle can yield different IgG-compositions. The results given above show that commercial preparations of IgG may differ, with respect to their composition, even when the immunoelectrophoresis patterns are identical. In general IgG components have iso-electric points at $\mathrm{pH} \geq 5.2$ but, unlike $\mathrm{ClgG}, \mathrm{KIgG}$ does not contain components in the low-pH range $(\mathrm{pH}<7.0)$. This is probably due to the ionexchange chromatography procedure used in the preparation of KigG.

Although both preparations show a high-affinity type adsorption isotherm, the ClgG-isotherm reaches a plateau value at low solution concentrations $\left(0.1 \mathrm{~g} \mathrm{I}^{-1}\right)$ whereas the $\mathrm{KIgG}$-isotherm has not reached a plateau even at $7.0 \mathrm{~g} \mathrm{l}^{-1}$. The observed differences in adsorption behaviour can only be explained in terms of differences in protein composition between the two preparations.

Our results emphasize the necessity for protein adsorption experiments to be accompanied by a thorough characterization of the protein(s) used. 


\section{REFERENCES}

1 Brash, J.L and Lyman, D.J., Adsorption of plasma proteins in solution to uncharged, hydrophobic polymer surfaces, J. Biomed. Mater. Res. 1969, 3. 175-189

2 Chuang, H.Y.K., King, W.F. and Mason, R.G., Interaction of plasma proteins with artificial surfaces: protein adsorption isotherms, J. Lab. Clin. Med. 1978, 92, 483-496

3 Eberhart, R.C., Lynch, M.E., Bilge, F.H., Wissinger, J.F., Munro, M.S., Ellsworth, S.R. and Quattrone, A.J., Protein adsorption on polymers. Visualization. study of fluid shear and roughness effects, and methods to enhance albumin binding, in Biomaterials: Interfacial Phenomena and Applications (Adv. Chem. Ser. 199), (Eds. S. L Cooper and N.A. Peppas) ACS, Washington D.C. (USA) 1982, pp 293-315

4 Soderquist, M.E. and Walton, A.G. Structural changes in proteins adsorbed on polymer surfaces. J. Colloid interf. Sci. 1980. 75, 386-397

$5 \quad$ Klein, C.P.A.T., de Groot, K, Vermeiden, J.P.W. and van Kamp, G. Interaction of some serum proteins with hydroxylapatite and other materials, J. Biomed. Mater. Res. 1980, 14, 705-712

6 Kim, S.W. and Lyman, D.J. Interfacing of polymers with blood Appl. Polym. Symp. 1973, 22, 289-297

7 Bagnall, R.D., Annis, J.A.D. and Sherliker, S.J., Adsorption of plasma proteins on hydrophobic surfaces. IV. Contact angle studies on implanted polymers, J. Biomed. Mater. Res. 1980 , 14, $1-10$

8 Young, B.R., Lambrecht, LK., Cooper, S.L and Mosher, D.F. Plasma proteins: their role in initiating platelet and fibrin deposition on biomaterials, in Biomaterials: Interfacial Phenomena and Applications (Adv. Chem. Ser. 199), (Eds. S.L. Cooper and N.A. Peppas) ACS, Washington D.C. (USA) 1982, pp 317-350
9 Baszkin, A and Lyman, D.J. The interaction of plasma proteins with polymers. I. Relationship between polymer surface energy and protein adsorption/desorption, J. Biomed. Mater. Res. $1980,14,393-403$

10 Kim, S.W. and Lee, E.S., The role of adsorbed proteins in platelet adhesion onto polymer surfaces, J. Polym. Sci.: Polym. Symp. $1979,66,429-441$

11 Horbett, T.A. and Weathersby, P.K., Adsorption of proteins from plasma to a series of hydrophilic-hydrophobic copolymers I. Analysis with the in situ radioiodination technique $J$. Biomed. Mater. Res. 1981, 15, 403-423

12 Beissinger, R.L and Leonard, E.F., Sorption kinetics of binary protein solutions: general approach to multi-component systems, J. Colloid Intert. Sci. 1982, 85, 521-533

13 Van Oss, C.J., Absolom, D.R., Neumann, A.W. and Zingg, W. Determination of the surface tension of proteins. I. Surface tension of native serum proteins in aqueous media, Biochim. Biophys. Acta 1981, 670, 64-73

14 Fair, B.D. and Jamieson, A.M. Studies of protein adsorption on polystyrene latex surfaces, J. Colloid Interf. Sci. 1980, 77, 525-534

15 Specifications given by the manufacture

16 Righetti, P.G. and Drysdale, J.W., Isoelectric focusing in gels, J. Chromatography 1974, 98, 271-321

17 Grabar, P. and Williams, C.A. Method permitting the simultaneous study of electrophoretic and immuno-chemical properties of a mixture of proteins. Application to blood serum, Biochim. et Biophys. Acta 1953, 10, 193-194

18 Klein Elhorst, J.T., Olthuis, F.M.F.G., Bargeman, D., Smolders, C.A and Feijen, J., The effect of radio-labelling of human fibrinogen on its adsorption behaviour on a polystyrene surface Int. J. Artif. Org. 1978, 1, 288-292 